\title{
Vitamin A and immunity to viral, bacterial and protozoan infections
}

\author{
R. D. Semba \\ Department of Ophthalmology, Johns Hopkins University School of Medicine, Baltimore, MD 21205, USA
}

\begin{abstract}
Studies in animal models and cell lines show that vitamin A and related retinoids play a major role in immunity, including expression of mucins and keratins, lymphopoiesis, apoptosis, cytokine expression, production of antibody, and the function of neutrophils, natural killer cells, monocytes or macrophages, $\mathrm{T}$ lymphocytes and B lymphocytes. Recent clinical trials suggest that vitamin A supplementation reduces morbidity and mortality in different infectious diseases, such as measles, diarrhoeal disease, measles-related pneumonia, human immunodeficiency virus infection and malaria. Immune responses vary considerably during different infections, and the available data suggest that the modulation of immune function by vitamin A may also vary widely, depending on the type of infection and immune responses involved.
\end{abstract}

Vitamin A: Immunity: Infection: Measles: Malaria

In the last two decades, considerable evidence has emerged that vitamin A plays an important role in immunity to infectious diseases. Perhaps more is known about how vitamin A modulates immune function than for any other micronutrient, yet there are still major gaps in our knowledge. Community- and hospital-based clinical trials have demonstrated that oral vitamin A supplementation or fortification can reduce preschool child mortality in developing countries by about one-third (Beaton et al. 1993). Recent experiments using animal and various cell lines suggest that vitamin $\mathrm{A}$ and related retinoids modulate many different immune response elements, including expression of keratins and mucins, lymphopoiesis, apoptosis, cytokine production, function of neutrophils, natural killer cells, monocytes or macrophages, $\mathrm{T}$ lymphocytes and $\mathrm{B}$ lymphocytes, and production of immunoglobulin (Ig; Semba, 1998). Regulation of immune responses by vitamin A and its active metabolites has been shown to occur via nuclear retinoic acid receptors at the level of the genome as well as via a pathway involving retroretinoids (Semba, 1998).

Although vitamin $\mathrm{A}$ and related retinoids have been shown to have important effects on immune function, the therapeutic value of vitamin A supplementation in enhancing immunity to different types of infections varies considerably. The purpose of the present paper is to gain an insight into the effects of vitamin $\mathrm{A}$ in modulating immune responses by comparing and contrasting its action during different types of infections, i.e. measles, diarrhoeal disease, respiratory disease, malaria, human immunodeficiency virus
(HIV) infection and tuberculosis. These comparisons suggest that the modulation of immune function by vitamin $\mathrm{A}$ is complex and involves many different arms of the immune system (Table 1).

\section{Measles}

Measles virus is a member of the Morbillivirus genus of the Paramyxoviridae, a family which includes rinderpest, peste des petits ruminants and canine distemper viruses (Bellini et al. 1994). Human subjects are generally considered to be the only natural host of this virus, but other primates can be infected through contacts with infected human subjects. Measles virus is spread from person-to-person via the respiratory route, and viral replication occurs in macrophages in the lymphoid tissue of the respiratory mucosa and lungs (Griffin, 1995). A viraemia allows measles virus to spread to multiple organs, including the skin, liver and conjunctiva, and a prodrome of fever, cough and conjunctivitis occurs approximately $14 \mathrm{~d}$ after infection. Antibody responses against measles virus proteins are detectable at the onset of the rash. Infants are protected against measles virus infection by passively acquired maternal antibody to measles, and this is probably the strongest evidence that antibody is involved in protective immunity to measles virus. T-cell-driven cellular immune responses, including activation of $\mathrm{CD} 4+$ and $\mathrm{CD} 8+$ lymphocytes, occur during measles (Griffin, 1995). Delayed-type hypersensitivity skin test responses and in 
Table 1. Vitamin A and immunity to infectious diseases

\begin{tabular}{|c|c|c|c|c|}
\hline \multirow[b]{2}{*}{ Disease } & \multirow[b]{2}{*}{ Immune response } & \multirow[b]{2}{*}{ Clinical effect of vitamin A } & \multicolumn{2}{|c|}{ Effects of vitamin A on immunity } \\
\hline & & & Human subjects & Animal models \\
\hline Measles & Primarily Th2-like response & $\downarrow$ Morbidity, mortality & $\begin{array}{l}\uparrow \text { IgG against measles } \\
\uparrow \text { Lymphocyte counts } \\
\downarrow \text { Measles replication? }\end{array}$ & $\begin{array}{l}\downarrow \text { Morbidity, } \uparrow \text { cytotoxic T-cell } \\
\text { responses to NDV in } \\
\text { chickens }\end{array}$ \\
\hline $\begin{array}{l}\text { Diarrhoeal } \\
\text { disease }\end{array}$ & $\begin{array}{l}\text { slgA response important; } \\
\text { immune response variable }\end{array}$ & $\downarrow$ Morbidity, mortality & Unknown & $\begin{array}{l}\downarrow \text { Morbidity, } \uparrow \text { slgA against } \\
\text { rotavirus in mice }\end{array}$ \\
\hline $\begin{array}{l}\text { Respiratory } \\
\text { disease }\end{array}$ & $\begin{array}{l}\text { Motility of cilia; alveolar } \\
\text { macrophages }\end{array}$ & $\begin{array}{l}\downarrow \text { Morbidity, mortality of measles- } \\
\text { associated pneumonia, little } \\
\text { effect on RSV, ALRI }\end{array}$ & Unknown & $\begin{array}{l}\downarrow \text { Morbidity, } \uparrow \text { slgA against } \\
\text { influenza A virus in mice }\end{array}$ \\
\hline Malaria & $\begin{array}{l}\text { Antibody and cell-mediated } \\
\text { immune responses, protective } \\
\text { immunity poorly defined }\end{array}$ & $\downarrow$ Morbidity & Unknown & $\downarrow$ Morbidity to $P$. berghei in rats \\
\hline HIV or AIDS & $\begin{array}{l}\text { Antibody and cell-mediated } \\
\text { immune responses }\end{array}$ & $\downarrow$ Morbidity, mortality & $\uparrow \mathrm{CD} 4+, \mathrm{NK}$ cell counts & Unknown \\
\hline Tuberculosis & Primarily Th1-like response & Unknown & Unknown & $\downarrow$ Morbidity to $M$. bovis in mice \\
\hline
\end{tabular}

Th2, T-helper cells type 2; slgA, secretory immunoglobulin A; RSV, respiratory syncytial virus, ALRI, acute lower-respiratory-tract infection, NDV, Newcastle disease virus, P. berghei, Plasmodium berghei; HIV, human immunodeficiency virus; AIDS, acquired immune deficiency syndrome; NK, natural killer; Th2, T-helper cells type $2 ; M$. bovis, Mycobacterium bovis; $\uparrow$, increase; $\downarrow$, decrease.

vitro proliferation of lymphocytes to viral antigens are often minimal or absent in measles infection (Griffin, 1995). Immune suppression often accompanies measles infection and is thought to increase the susceptibility to secondary infections. The immune response to measles is thought to be consistent with T-helper (Th) 2-like immune responses in which antibody responses predominate and are driven by interleukin-(IL) 4, IL-6 and IL-10. Measles virus infection of primary human monocytes has been shown to suppress cell-mediated immunity through down-regulation of IL-12 production (Karp et al. 1996).

Some determinants of clinical outcome during measles infection include vitamin A status (Markowitz et al. 1989), overcrowding and virus dose (Aaby, 1988), and malnutrition (Alwar, 1992). Clinical trials show that high-dose vitamin A supplementation reduces morbidity and mortality in children with acute measles infection (Barclay et al. 1987; Hussey \& Klein, 1990; Coutsoudis et al. 1991; Ogaro et al. 1993). In acute complicated measles, high-dose vitamin A supplementation (60 mg retinol equivalents (RE) on admission and the following day) has been shown to reduce mortality by up to $80 \%$ in Cape Town, South Africa (Hussey \& Klein, 1990). Vitamin A supplementation seems to reduce the infectious complications associated with measles immune suppression, such as pneumonia and diarrhoeal disease.

There have been no published animal studies (such as in experimentally-infected primates) which provide directly relevant information on how vitamin A status influences immune responses to measles virus. Canine distemper virus shares some sequences and similar proteins to measles virus, and there is potential for examining the effects of vitamin A status on canine distemper virus infection in dogs. Newcastle disease virus, another virus in the family Paramyxoviridae, is a well-studied animal model which might provide useful inferences for the effects of vitamin A status on immune responses during measles. Vitamin Adeficient chickens infected with Newcastle disease virus show immunological abnormalities such as increased virus shedding, decreased numbers of $\mathrm{T}$ and $\mathrm{B}$ lymphocytes in peripheral blood, and impaired cytotoxic $\mathrm{T}$ lymphocyte responses against Newcastle disease virus-infected cells (Sijtsma et al. 1990; West et al. 1991).

There are some findings which suggest how vitamin A supplementation modulates immune responses during measles virus infection. Children with acute measles infection who received high-dose vitamin A supplementation (60 mg RE on admission and the following day) had higher $\mathrm{IgG}$ responses to measles virus and higher circulating lymphocyte counts during follow-up compared with children who received placebo (Coutsoudis et al. 1992). These results are consistent with the observation that vitamin A supplementation may enhance lymphopoiesis (Göttgens \& Green, 1995). In a clinical trial in Indonesia, high-dose vitamin A supplementation increased circulating CD4+ lymphocytes, especially naive CD4+ cells (Semba et al. 1993).

Perhaps a clue as to how vitamin A may modulate immunity to measles comes from three studies in which a high-dose vitamin A supplement was administered with live attenuated measles vaccine. In a clinical trial in Indonesia, high-dose vitamin A supplementation (60 mg RE 2 weeks before immunization) was shown to increase $\mathrm{IgG}$ responses to tetanus toxoid in preschool children, aged 3-6 years, who received diphtheria-pertussis-tetanus immunization (Semba et al. 1992). This observation provided the rationale that high-dose vitamin A supplementation given with measles vaccination might enhance antibody responses to measles virus. In 6-month-old infants in Indonesia, administration of vitamin A (30 mg RE) at the time of immunization with standard titre Schwarz measles vaccine interfered with seroconversion to measles in infants who had maternal antibody present, and reduced the incidence of measles vaccineassociated rash (Semba et al. 1995). A separate clinical trial also showed that vitamin A (30 mg RE) reduced antibody responses to measles virus in 9-month-old infants who had maternal antibody present, but did not interfere with overall seroconversion rates to measles (Semba et al. 1997).

In a study in Guinea-Bissau, vitamin A supplementation (30 mg RE) was found to enhance geometric mean titres to 
measles when given simultaneously with standard titre Schwarz measles vaccine in 9-month-old infants (Stabell Benn et al. 1997). In a two-dose measles immunization schedule at ages 6 and 9 months, simultaneous vitamin A supplementation did not interfere with seroconversion to measles when measured at 18 months of age (Stabell Benn et al. 1997). It is not possible to determine whether vitamin A supplementation interfered with seroconversion rates after measles vaccine in 6-month-old infants in the study in Guinea-Bissau (Stabell Benn et al. 1997) as it did in the study in Indonesia (Semba et al. 1995), because antibody titres were not measured until after two doses of measles vaccine. Although the results of the studies in Indonesia and Guinea-Bissau involving 6-month-old infants have been viewed as contradictory (Ross \& Cutts, 1997; Stabell Benn et al. 1997), the differences in the design of measles vaccine studies lends little validity to making direct comparisons of these two studies. The findings may be complementary (Semba, 1997).

How does vitamin A supplementation enhance immunity to measles? Is there an increase in Th2-like responses with enhancement of antibody titres to measles? Such an effect might be predicted on the basis of a murine model which suggests that vitamin A status influences the balance between Th1- and Th2-like responses (Cantorna et al. 1994), and this effect is consistent with the findings of a study of children in South Africa (Coutsoudis et al. 1992). Do vitamin A and related retinoids enhance natural killer cell activity against measles virus, as has been suggested in a rat model of vitamin A deficiency (Zhao \& Ross, 1995)? Alternatively, does vitamin A have an impact directly on the replication of measles virus? If a retinoic acid response element were present in the measles genome, it might provide a clue as to potential regulation of measles virus replication by vitamin $\mathrm{A}$ and related retinoids.

\section{Diarrhoeal disease}

In developing countries, diarrhoeal diseases among children are caused by a wide variety of pathogens, including rotavirus, Escherichia coli, and Shigella, Vibrio cholerae, Salmonella and Entamoeba histolytica. The epidemiology, clinical features, immunology and pathogenesis of diarrhoea may differ according to characteristics of the pathogen, such as production of toxins, tissue invasion, fluid and electrolyte loss, and location of infection. In general, host defences in the gut include gastric acidity, the presence of normal microflora, gut motility, mucus production, integrity of microvilli, local secretion of antibody and cell-mediated immunity. The development of protective immunity to rotavirus involves the generation of secretory $\operatorname{IgA}$ antibodies against rotavirus in the gut and serum (Grimwood et al. 1988; Bernstein et al. 1989; Coulson, 1998).

Clinical vitamin A deficiency is associated with diarrhoeal disease in children (Brilliant et al. 1985; DeSole et al. 1987; Gujral et al. 1993; Schaumberg et al. 1996). A large longitudinal study in Indonesia has shown that children with pre-existing xerophthalmia are at a higher risk of having a subsequent episode of diarrhoeal disease (Sommer et al. 1984). Recent large community-based clinical trials of vitamin A supplementation in Tamil Nadu,
Nepal and Ghana show that vitamin A has a major impact on the overall mortality from diarrhoeal disease (Sommer \& West, 1996). In a clinical trial in Brazil the severity of diarrhoeal disease was shown to be reduced by vitamin A supplementation (Barreto et al. 1994). Urinary losses of vitamin A during Shigella infection may be substantial in some children (Mitra et al. 1998), and vitamin A supplementation ( $60 \mathrm{mg} \mathrm{RE}$ ) has recently been shown to reduce morbidity in children with acute shigellosis (Hossain et al. 1998).

Although vitamin A supplementation reduces morbidity and mortality from diarrhoeal disease in general, it is unclear whether vitamin A enhances immunity against all diarrhoeal pathogens or has effects specific for certain organisms. The effect of vitamin A on mucosal immunity in human subjects has not been addressed. The results of autopsy studies of children obtained from the older literature suggest that vitamin A deficiency is associated with alterations in the gut epithelia (Blackfan \& Wolbach, 1933; Sweet \& K'ang, 1935), but it is likely that other concomitant nutritional abnormalities were present at time of death. A mouse model using epizootic diarrhoea of infant mice rotavirus strain has been used to gain an insight into the effects of vitamin A status on immunity to infection. Vitamin A-deficient mice were much more susceptible to rotavirus infection and had greater pathology in the gut, including destruction of microvilli (Ahmed et al. 1990). Following challenge with epizootic diarrhoea of infant mice rotavirus, serum antibody responses against the rotavirus were significantly lower in vitamin A-deficient mice than in control or pair-fed mice (Ahmed et al. 1991). The secretory IgA response against rotavirus was not specifically measured in this mouse study; however, studies in mice and human subjects suggest that serum $\operatorname{IgA}$ and $\operatorname{IgG}$ may be useful indicators of immunity to rotavirus (Grimwood et al. 1988; Bernstein et al. 1989; McNeal \& Ward, 1995).

\section{Respiratory disease}

Acute lower-respiratory-tract infections are a major cause of death among children in developing countries, and major causes of acute lower-respiratory-tract infections include respiratory syncytial virus infection, parainfluenza, Haemophilus influenzae, Streptococcus pneumoniae and Bordetella pertussis. Secondary bacterial infection with high case fatality may follow a primary viral infection in the lungs. Important components of the immune response in the respiratory tract include motility of cilia, mucin production and the activity of alveolar macrophages. The immune response to different respiratory pathogens may vary greatly. For example, immunity to respiratory syncytial virus infection in infants seems to be associated with a Th2-like response characterized by interferon $\gamma$ and IL-2 production (Roman et al. 1997), whereas immunity to whooping cough seems to be associated with a Th1-like response (Ryan et al. 1997a, b).

Vitamin A deficiency causes pathological alterations in the epithelium of the respiratory tract, including keratinization and loss of ciliated cells, mucus, and goblet cells. Clinical vitamin A deficiency is associated with lowerrespiratory-tract infections (DeSole et al. 1987; Tielsch 
et al. 1986). A large longitudinal study in Indonesia suggested that preschool children with mild xerophthalmia are at an increased risk of having a subsequent episode of respiratory infection (Sommer et al. 1984). These natural history studies suggested that vitamin A supplementation might reduce morbidity and mortality from respiratory disease. Community-based clinical trials have attempted to determine whether periodic high-dose vitamin A supplementation reduces the incidence and/or severity of acute respiratory infections in children. Hospital-based clinical trials have addressed whether high-dose vitamin A supplementation can reduce morbidity when given at the time of an acute attack of respiratory disease.

The community-based trials of vitamin A supplementation did not seem to reduce the incidence of acute lower-respiratory-tract infections, although there was an overall beneficial effect in reducing child mortality (The Vitamin A and Pneumonia Working Group, 1995). Vitamin A supplementation, when delivered through childhood immunization programmes, may reduce the duration of acute respiratory infections among infants (Rahman et al. 1996). Hospital-based studies have shown that high-dose vitamin A supplementation has no therapeutic effect on the morbidity of acute lower-respiratory-tract infections in children (Kjolhede et al. 1995; Nacul et al. 1997; Fawzi et al. 1998a). In Chile and the USA, hospital-based trials showed that vitamin A supplementation had little impact on respiratory syncytial virus infection among infants and young children (Bresee et al. 1996; Dowell et al. 1996; Quinlan \& Hayani, 1996).

Although vitamin A status has been shown to be related to the severity of acute respiratory infection in children (Dudley et al. 1997), it is unclear why in some trials vitamin A therapy has no apparent effect on the morbidity of acute respiratory infections among preschool children. Young age might be one contributing factor to the lack of an effect, as large community-based studies suggest that vitamin A supplementation has little effect on morbidity and mortality of infants (West et al. 1995; WHO/CHD ImmunisationLinked Vitamin A Supplementation Study Group, 1998). Studies have been conducted also in populations where vitamin A deficiency is not considered a public health problem. In the recent clinical trials involving respiratory syncytial virus infection, the apparent lack of impact of vitamin A supplementation on respiratory syncytial virus infection might be due to the young age of the subjects and the lack of vitamin A deficiency in the population. Other micronutrient deficiencies, such as that of vitamin $\mathrm{D}$ and $\mathrm{Zn}$, may have limiting roles in immunity to respiratory infections (Muhe et al. 1997; Ruel et al. 1997).

An animal model of influenza A virus infection in mice has been used to study the effects of vitamin A deficiency on immune responses. Vitamin A-deficient mice had impaired regeneration of normal respiratory epithelium following infection, and the secretory $\operatorname{Ig} \mathrm{A}$ response in the respiratory tract was decreased by vitamin A deficiency (Stephensen et al. 1993). Vitamin A deficiency was associated with decreased salivary IgA responses but increased serum IgG responses against influenza $\mathrm{A}$ virus in severely-infected mice (Stephensen et al. 1996). The decreased secretory IgA responses against influenza $\mathrm{A}$ virus appear to be due to lower numbers of IgA-secreting plasma cells in vitamin Adeficient mice compared with control mice (Gangopadhyay et al. 1996). The studies in this murine model suggest that vitamin A deficiency would impair immunity against viral infections in the respiratory tract, and further research is needed to determine the effects of vitamin A deficiency against respiratory pathogens in human subjects. It would be erroneous to consider vitamin $\mathrm{A}$ as ineffective in increasing immunity to acute lower-respiratory-tract infections; vitamin A supplementation has been shown to reduce the life-threatening complication of pneumonia after acute measles infection (Barclay et al. 1987; Hussey \& Klein, 1990).

\section{Malaria}

Malaria is a mosquito-borne protozoan disease which is caused by Plasmodium falciparum, $P$. vivax, $P$. malariae and $P$. ovale in human subjects, of which $P$. falciparum is the most serious, causing an estimated one to two million deaths worldwide each year (Murphy \& Oldfield, 1996). In the life cycle of $P$. falciparum, sporozoites are inoculated with the saliva of a biting mosquito into the blood of the human host, and within minutes the sporozoites reach the liver and invade hepatocytes. During the pre-erythrocytic cycle in the liver, a sporozoite can develop into a mature liver schizont, which can burst, releasing thousands of merozoites into the blood. The merozoites infect human erythrocytes and initiate the erythrocytic cycle. Merozoites mature into blood schizonts which burst, producing eight to thirty-two new merozoites that can invade more erythrocytes. Symptoms such as fever and malaise are produced during the infection, rupture and destruction of erythrocytes. Within 10-12 d sexual forms of $P$. falciparum (male and female gametocytes) appear in the peripheral blood and can be taken up by the mosquito during a blood meal. In the mosquito, gametocytes undergo development into zygotes, ookinetes, and oocysts, and eventually sporozoites.

Immunity to malaria occurs over several years of exposure to repeated infection, and it may take years to develop immunity to the full range of antigenic variation of the parasite (Reeder \& Brown, 1996; Baird, 1998). Antibody-mediated immunity, cell-mediated responses and non-specific immunity comprise the immune response against $P$. falciparum, and complete immunity against re-infection is not known. Antibody responses are directed against many stages in the life cycle of $P$. falciparum, including circumsporozoite protein, merozoite surface antigens 1 and 2, apical membrane antigen 1 and Pf155/ringinfected erythrocyte surface antigens. The results of a recent cohort study from Ghana suggest that the level of maternal antibody may help protect young infants from infection (Wagner et al. 1998); these findings may help to explain the increasing prevalence of clinical $P$. falciparum infection with increasing age during the first year of life. Lymphocyte proliferation responses to various malarial antigens have been observed, but their significance is unclear (Høgh, 1996).

Natural history studies suggest an association between indicators of poor vitamin A status and malaria (Stürchler 
et al. 1987; Galan et al. 1990; Friis et al. 1997). A recent randomized placebo-controlled clinical trial was conducted in Papua New Guinea to examine the effects of vitamin A supplementation (60 mg RE every 3 months) on malarial morbidity in preschool children (Shankar et al. 1997). Children between 6 and 60 months of age were randomized to receive vitamin A or placebo every 3 months. Weekly morbidity surveillance and clinic-based surveillance were established to monitor acute malaria, and children were followed for 1 year. Vitamin A significantly reduced the incidence of malaria attacks by about $20-50 \%$ for all except extremely high levels of parasitaemia. Similarly, vitamin A supplementation reduced 'clinic-based' malaria attacks, which consisted of self-solicited visits to the clinic by mothers who thought that their children should be seen because of fever. Vitamin A supplementation had little impact in children under age 12 months and greatest effect from 13 to 36 months of age.

Although the effects of vitamin A deficiency on susceptibility to malaria have been examined in a rat model (Stoltzfus et al. 1989), it is unclear how vitamin A status influences immune responses to malaria. The clinical trial of vitamin A supplementation in Papua New Guinea involved laboratory analyses of antibody responses to malaria antigens, T-cell subsets and lymphocyte proliferation responses to mitogens and malaria antigens, and these studies are currently in progress. Clearly, it will be important to identify underlying immunological mechanisms which might explain the observations of reduced malarial morbidity in children who received vitamin A.

\section{Human immunodeficiency virus infection}

During HIV infection, microenteropathy, malabsorption, steatorrhoea and anorexia are not uncommon, and low plasma or serum vitamin A levels have been described in all stages of HIV infection and among many different risk groups (Semba \& Tang, 1999). Plasma or serum levels of vitamin A or intake of vitamin A has been associated with increased disease progression, mortality and higher motherto-child transmission of HIV (Semba et al. 1994; Semba \& Tang, 1999). Periodic high-dose vitamin A supplementation seems to reduce morbidity among children born to HIVinfected mothers (Coutsoudis et al. 1995), but vitamin A supplementation itself does not appear to influence HIV load in the blood (Semba et al. 1998). Providing multivitamin supplementation to HIV-infected women during pregnancy reduces fetal mortality and low birth weight by about $40 \%$, but vitamin A supplementation alone had no significant impact (Fawzi et al. 1998c). High-dose vitamin A supplementation appeared to reduce mortality among HIV-infected children who presented with acute lowerrespiratory tract infection (Fawzi et al. 1998b).

Low plasma vitamin A levels have been associated with T-cell subset abnormalities such as decreased CD4+ lymphocytes and decreased CD3+CD28+ lymphocytes in injection drug users (Semba et al. 1996). In children with acquired immune deficiency syndrome in Cape Town vitamin A supplementation was shown to increase circulating CD4+ lymphocytes and natural killer cells 1 month following high-dose vitamin A supplementation (60 mg RE on consecutive days; Hussey et al. 1996). Again, these observations are consistent with the hypothesis that vitamin A status influences lymphopoiesis. Studies of the effects of vitamin A status on functional immunity have not been conducted in subjects with HIV infection. Although retrovirus infection in mice has been used as a model for HIV infection (Watson et al. 1988), this infection is not similar in that the virus infects both $\mathrm{B}$ and $\mathrm{T}$ lymphocytes in mice rather than CD4+ lymphocytes as it does in HIV infection.

\section{Tuberculosis}

Mycobacterium tuberculosis infection is usually spread by the respiratory route, and infection by tubercle bacilli can result in asymptomatic infection or clinical tuberculosis. The vast majority of primary infections do not result in clinical infection; however, in individuals with poor nutritional status, the risk of developing pulmonary or miliary tuberculosis is greatly increased.

Although malnutrition and vitamin A deficiency seem to be major risk factors for the progression of tuberculosis, clinical management usually involves chemoprophylaxis and chemotherapy alone, rather than improvement of host nutritional status. Cod-liver oil, a rich source of vitamins A and D, was used as treatment for tuberculosis for over 100 years. The role of nutrition in tuberculosis remains a major area of neglect, despite the promise that micronutrients have shown as therapeutic agents for other types of infections, and the long record of the use of vitamins A and D for treatment of pulmonary and miliary tuberculosis in both Europe and the USA. A recent clinical trial suggests that high-dose vitamin A supplementation does not influence the morbidity of tuberculosis in children (Hanekom et al. 1997). Studies which address the use of multivitamins and minerals or vitamins A plus D as adjunct therapy for tuberculosis have not yet been conducted.

In animal models immunity against $M$. tuberculosis is most consistent with a Th1-like response, with predomination of interferon $\gamma$ and IL-12 (Hernández-Pando et al. 1996; Cooper et al. 1997). Cytotoxic T lymphocytes (Lalvani et al. 1998) and natural killer cells (Yoneda \& Ellner, 1998) also appear to play an important role in resistance to $M$. tuberculosis. Macrophages are a key element in host resistance to tubercle bacilli. Activated macrophages destroy tubercle bacilli, and whether a tuberculous lesion progresses or regresses is largely dependent on the ability of macrophages which enter the granulation tissue to ingest and destroy bacilli (Dannenberg, 1989).

Vitamin A-deficient animals have decreased resistance to experimental infection with Mycobacterium spp. Among animals inoculated with virulent tubercle bacilli, mortality was higher among vitamin A-deficient rats than rats on a normal diet (Gloyne \& Page, 1921). In another study of experimental tuberculosis infection, vitamin A-deficient rats had more severe infection and more extensive lesions on histopathology than control rats (Sriramachari \& Gopalan, 1958). In addition, rats given adequate vitamin A but restricted in protein or energy were not more susceptible to experimental tuberculosis infection, suggesting that increased susceptibility to tuberculosis was attributable to lack of vitamin A rather than protein-energy malnutrition. 
Vitamin A-deficient mice have a more severe infection with $M$. bovis compared with mice supplemented with dietary $\beta$-carotene (Finkelstein, 1932). Chicks fed on a highvitamin A diet had $26 \%$ increased survival compared with chicks fed on a normal diet following experimental infection with M. tuberculosis (Solotorovsky et al. 1961). Production of IL-1 by macrophages is dependent on vitamin A status in experimental animal models (Moriguchi et al. 1985). Dietary vitamin A enhances T-cell proliferation responses and antibody responses to $M$. tuberculosis antigen in the chick model (Sklan et al. 1994). Vitamin A-supplemented mice challenged with $M$. bovis and treated with IL-2 have strong delayed-type hypersensitivity responses and proliferation responses to purified protein derivative compared with control mice without supplementary vitamin A (Ferraro et al. 1988).

\section{Conclusions}

The available information suggests that immune modulation by vitamin A during infections may depend on the pathogen or pathogens involved. The type of antigens, the level of T-cell activation and the local cytokine environment may all influence the modulation of immune response following vitamin A supplementation. As seems apparent from examination of different diseases, the modulation of immune responses by vitamin A does not seem to fit a clear Th1 $v$. Th2 type of pattern. During measles infection vitamin A seems to be enhancing Th2-like responses with potentiation of antibody responses to measles virus. The use of cod-liver oil for treatment of tuberculosis suggests that this therapy may have an effect on Th1-like immune responses against $M$. tuberculosis, but it may be difficult to attribute these effects to vitamin A alone, as cod-liver oil is a rich source of vitamins $\mathrm{A}$ and $\mathrm{D}$ and other nutrients. One study suggests that vitamin A supplementation enhances delayed-type hypersensitivity skin responses in infants (Rahman et al. 1997), consistent with modulation of Th1-like responses. In human subjects, it has been somewhat difficult to study immune modulation by vitamin A in certain disease states, such as respiratory and diarrhoeal disease, given the wide variety of pathogens involved in such infections. Measles is probably the most well-defined illness for the study of immune modulation by vitamin A. Further studies are needed to elucidate the ways in which vitamin A enhances immunity to malaria. A large gap remains between studies of immune modulation by vitamin $\mathrm{A}$ and its metabolites in cell lines and studies of immune modulation by vitamin $\mathrm{A}$ in human subjects (Semba, 1998).

\section{Acknowledgements}

This work was supported in part by the National Institute of Health (HD30042, HD32247, AI41956), the Fogarty International Center and the United States Agency for International Development (Cooperative Agreement HRNA-00-97-00015-00).

\section{References}

Aaby P (1988) Malnutrition and overcrowding/intensive exposure in severe measles infection: review of community studies. Reviews of Infectious Disease 10, 478-491.

Ahmed F, Jones DB \& Jackson AA (1990) The interaction of vitamin A deficiency and rotavirus infection in the mouse. British Journal of Nutrition 63, 363-373.

Ahmed F, Jones DB \& Jackson AA (1991) Effect of vitamin A deficiency on the immune response to epizootic diarrhoea of infant mice (EDIM) rotavirus infection in mice. British Journal of Nutrition 65, 475-485.

Alwar AJE (1992) The effect of protein energy malnutrition on morbidity and mortality due to measles at Kenyatta National Hospital, Nairobi, Kenya. East African Medical Journal 69, 415-418.

Baird JK (1998) Age-dependent characteristics of protection $v$. susceptibility to Plasmodium falciparum. Annals of Tropical Medicine and Parasitology 92, 367-390.

Barclay AJG, Foster A \& Sommer A (1987) Vitamin A supplements and mortality related to measles: a randomised clinical trial. British Medical Journal 323, 160-164.

Barreto ML, Santos LMP, Assis AMO, Purificação M, Araújo N, Farenzena GG, Santos PAB \& Fiaccone RL (1994) Effect of vitamin A supplementation on diarrhoea and acute lowerrespiratory-tract infections in young children in Brazil. Lancet 344, 228-231.

Beaton GH, Martorell R, L'Abbe KA, Edmonston B, McCabe G, Ross AC \& Harvey B (1993) Effectiveness of Vitamin A Supplementation in the Control of Young Child Morbidity and Mortality in Developing Countries. ACC/SCN State-of-the-Art Nutrition Policy Discussion Paper no. 13. Geneva: UN.

Bellini WJ, Rota JS \& Rota PA (1994) Virology of measles virus. Journal of Infectious Diseases 170, Suppl. 1, S15-S23.

Bernstein DI, McNeal MM, Schiff GM \& Ward RL (1989) Induction and persistence of local rotavirus antibodies in relation to serum antibodies. Journal of Medical Virology 28, 90-95.

Blackfan KD \& Wolbach SG (1933) Vitamin A deficiency in infants: a clinical and pathological study. Journal of Pediatrics $\mathbf{3}$, 679-706.

Bresee JS, Fischer M, Dowell SF, Johnston BD, Biggs VM, Levine RS, Lingappa JR, Keyserling HL, Petersen KM, Bak JR, Gary HE, Sowell AL, Rubens CE \& Anderson LJ (1996) Vitamin A therapy for children with respiratory syncytial virus infection: a multicenter trial in the United States. Pediatric Infectious Diseases Journal 15, 777-782.

Brilliant LB, Pokhrel RP, Grasset NC, Lepkowski JM, Kolstad A, Hawks W, Pararajasegaram R, Brilliant GE, Gilbert S, Shrestha SR \& Kuo J (1985) Epidemiology of blindness in Nepal. Bulletin of the World Health Organization 63, 375-386.

Cantorna MT, Nashold FE \& Hayes CE (1994) In vitamin A deficiency multiple mechanisms establish a regulatory $\mathrm{T}$ helper cell imbalance with excess Th1 and insufficient Th2 function. Journal of Immunology 152, 1515-1522.

Cooper AM, Magram J, Ferrante J \& Orme IM (1997) Interleukin 12 (IL-12) is crucial to the development of protective immunity in mice intravenously infected with Mycobacterium tuberculosis. Journal of Experimental Medicine 186, 39-45.

Coulson BS (1998) Longitudinal studies of neutralizing antibody responses to rotavirus in stools and sera of children following severe rotavirus gastroenteritis. Clinical and Diagnostic Laboratory Immunology 5, 897-901.

Coutsoudis A, Bobat RA, Coovadia HM, Kuhn L, Tsai WY \& Stein ZA (1995) The effects of vitamin A supplementation on the morbidity of children born to HIV-infected women. American Journal of Public Health 85, 1076-1081. 
Coutsoudis A, Broughton M \& Coovadia HM (1991) Vitamin A supplementation reduces measles morbidity in young African children: a randomized, placebo-controlled, double-blind trial. American Journal of Clinical Nutrition 54, 890-895.

Coutsoudis A, Kiepiela P, Coovadia HM \& Broughton M (1992) Vitamin A supplementation enhances specific IgG antibody levels and total lymphocyte numbers while improving morbidity in measles. Pediatric Infectious Diseases Journal 11, 203-209.

Dannenberg AM Jr (1989) Immune mechanisms in the pathogenesis of pulmonary tuberculosis. Reviews of Infectious Diseases 11, Suppl. 2, S369-S378.

DeSole G, Belay Y \& Zegeye B (1987) Vitamin A deficiency in southern Ethiopia. American Journal of Clinical Nutrition 45, 780-784.

Dowell SF, Papic Z, Bresee JS, Larrañaga C, Mendez M, Sowell AL, Gary HE, Anderson LJ \& Avendaño LF (1996) Treatment of respiratory syncytial virus infection with vitamin A: a randomized, placebo-controlled trial in Santiago, Chile. Pediatric Infectious Diseases Journal 15, 782-786.

Dudley L, Hussey G, Huskissen J \& Kessow G (1997) Vitamin A status, other risk factors and acute respiratory infection morbidity in children. South African Medical Journal 87, 65-70.

Fawzi WW, Mbise RL, Fataki MR, Herrera MG, Kawau F, Hertzmark E, Spiegelman D \& Ndossi G (1998a) Vitamin A supplementation and severity of pneumonia in children admitted to the hospital in Dar es Salaam, Tanzania. American Journal of Clinical Nutrition 68, 187-192.

Fawzi W, Mbise FL, Kawau F, Herrera MG, Hertzmark E, Fataki M \& Spiegelman G (1998b) Vitamin A supplements and mortality among HIV positive and negative children in Tanzania. Abstracts of the $12^{\text {th }}$ World AIDS Conference, Geneva, June 28 July 3, 1998, p. 840, Abstr. 170/42331, Geneva: 12th World Aids Conference Committee.

Fawzi WW, Msamanga GI, Spiegelman D, Urassa EJN, McGrath N, Mwakagile D, Antelman G, Mbise R, Herrera G, Kapiga S, Willett W, Hunter DJ \& Tanzania Vitamin and HIV Infection Trial Team (1998c) Randomised trial of effects of vitamin supplements on pregnancy outcomes and T cell counts in HIV-1infected women in Tanzania. Lancet 351, 1477-1482.

Ferraro F, Mattei M \& Colizzi V (1988) Low doses of recombinant interleukin-2 enhanced delayed type hypersensitivity to PPD in mice infected with Mycobacterium bovis-BCG and fed a diet supplemented with vitamin A acetate. Zeitschrift für Erkrankungen der Atmungsorgane 171, 45-49.

Finkelstein MH (1932) Effect of carotene on course of $B$. tuberculosis infection of mice fed on a vitamin A deficient diet. Proceedings of the Society for Experimental Biology and Medicine 29, 69-71.

Friis H, Mwaniki D, Omondi B, Muniu E, Magnussen P, Geissler W, Thiong'o F \& Michaelsen KF (1997) Serum retinol concentrations and Schistosoma mansoni intestinal helminths, and malarial parasitemia: a cross-sectional study in Kenyan preschool and primary school children. American Journal of Clinical Nutrition 66, 665-671.

Galan P, Samba C, Luzeau R \& Amedee-Manesme O (1990) Vitamin A deficiency in preschool age Congolese children during malaria attacks. Part 2: impact of parasitic disease on vitamin A status. International Journal of Vitamin and Nutrition Research 60, 224-228.

Gangopadhyay NN, Moldoveanu Z \& Stephensen CB (1996) Vitamin A deficiency has different effects on immunoglobulin A production and transport during influenza $\mathrm{A}$ infection in BALB/c mice. Journal of Nutrition 126, 2960-2967.

Gloyne SR \& Page DS (1921) A preliminary note on the relationship between deficiency in vitamin $\mathrm{A}$ and tuberculosis. Tubercle 3, 577-579.
Göttgens B \& Green AR (1995) Retinoic acid and the differentiation of lymphohaemapoietic stem cells. Bioessays 17, 187-189.

Griffin DE (1995) Immune responses during measles virus infection. Current Topics in Microbiology and Immunology 191, 117-134.

Grimwood K, Lund JC, Coulson BS, Hudson IL, Bishop RF \& Barnes GL (1988) Comparison of serum and mucosal antibody responses following severe acute rotavirus gastroenteritis in young children. Journal of Clinical Microbiology 26, 732-738.

Gujral S, Abbi R \& Gopaldas T (1993) Xerophthalmia, vitamin A supplementation and morbidity in children. Journal of Tropical Pediatrics 39, 89-92.

Hanekom WA, Potgieter S, Hughes EJ, Malan H, Kessow G \& Hussey GD (1997) Vitamin A status and therapy in childhood pulmonary tuberculosis. Journal of Pediatrics 131, 925-927.

Hernández-Pando R, Orozcoe H, Sampieri A, Pavón L, Velasquillo C, Larriva-Sahd J, Alcocer JM \& Madrid MV (1996) Correlation between the kinetics of Th1/Th2 cells and pathology in a murine model of experimental pulmonary tuberculosis. Immunology $\mathbf{8 9}$, 26-33.

Høgh B (1996) Clinical and parasitological studies on immunity to Plasmodium falciparum malaria in children. Scandinavian Journal of Infectious Diseases 102, Suppl., 1-53.

Hossain S, Biswas R, Kabir I, Sarker S, Dibley M, Fuchs G \& Mahalanabis D (1998) Single dose vitamin A treatment in acute shigellosis in Bangladeshi children: randomised double blind controlled trial. British Medical Journal 316, 422-426.

Hussey G, Hughes J, Potgieter S, Kessow G, Burgess J, Beatty D, Keraan M \& Carlesle E (1996) Vitamin A status and supplementation and its effects on immunity in children with AIDS. In Abstracts of the XVII International Vitamin A Consultative Group Meeting, Guatemala City, p. 6. Washington, DC: International Life Sciences Institute.

Hussey GD \& Klein M (1990) A randomized, controlled trial of vitamin A in children with severe measles. New England Journal of Medicine 323, 160-164.

Karp CL, Wysocka M, Wahl LM, Ahearn JM, Cuomo PJ, Sherry B, Trinchieri G \& Griffin DE (1996) Mechanism of suppression of cell-mediated immunity by measles virus. Science 273, $228-231$.

Kjolhede CL, Chew FJ, Gadomski AM \& Marroquin DP (1995) Clinical trial of vitamin A as adjuvant treatment for lower respiratory tract infections. Journal of Pediatrics 126, 807-812.

Lalvani A, Brookes R, Wilkinson RJ, Malin AS, Pathan AA, Andersen P, Dockrell H, Pasvol G \& Hill AVS (1998) Human cytolytic and interferon $\gamma$-secreting CD8+ T lymphocytes specific for Mycobacterium tuberculosis. Proceedings of the National Academy of Sciences USA 95, 270-275.

McNeal MM \& Ward RL (1995) Long-term production of rotavirus antibody and protection against reinfection following a single infection of neonatal mice with murine rotavirus. Virology 211, 474-480.

Markowitz L, Nzilambi N, Driskell WJ, Sension MG, Rovira EZ, Nieburg P \& Ryder RW (1989) Vitamin A levels and mortality among hospitalized measles patients, Kinshasa, Zaire. Journal of Tropical Pediatrics 35, 109-112.

Mitra AK, Alvarez JO, Guay-Woodford L, Fuchs GJ, Wahed MA \& Stephensen CB (1998) Urinary retinol excretion and kidney function in children with shigellosis. American Journal of Clinical Nutrition 68, 1095-1103.

Moriguchi S, Werner L \& Watson RR (1985) High dietary vitamin A (retinyl palmitate) and cellular immune functions in mice. Immunology 56, 169-177.

Muhe L, Lulseged S, Mason KE \& Simoes EAF (1997) Case-control study of the role of nutritional rickets in the risk 
of developing pneumonia in Ethiopian children. Lancet 349, 1801-1804.

Murphy GS \& Oldfield EC (1996) Falciparum malaria. Infectious Disease Clinics of North America 10,747-775.

Nacul LC, Kirkwood BR, Arthur P, Morris SS, Magalhães M \& Fink MCDS (1997) Randomised, double blind, placebo controlled clinical trial of efficacy of vitamin A treatment in nonmeasles childhood pneumonia. British Medical Journal 315, 505-510.

Ogaro FO, Orinda VA, Onyango FE \& Black RE (1993) Effect of vitamin A on diarrhoeal and respiratory complications of measles. Tropical and Geographical Medicine 45, 283-286.

Quinlan KP \& Hayani KC (1996) Vitamin A and respiratory syncytial virus infection. Serum levels and supplementation trial. Archives of Pediatric and Adolescent Medicine 150, 25-30.

Rahman MM, Mahalanabis D, Alvarez JO, Wahed MA, Islam MA \& Habte D (1997) Effect of early vitamin A supplementation on cell-mediated immunity in infants younger than 6 mo. American Journal of Clinical Nutrition 65, 144-148.

Rahman MM, Mahalanabis D, Alvarez JO, Wahed MA, Islam MA, Habte D \& Khaled MA (1996) Acute respiratory infections prevent improvement of vitamin A status in young infants supplemented with vitamin A. Journal of Nutrition 126, 628633.

Reeder JC \& Brown GV (1996) Antigenic variation and immune evasion in Plasmodium falciparum malaria. Immunology and Cell Biology 74, 546-554.

Roman M, Calhoun WJ, Hinton KL, Avendano LF, Simon V, Escobar AM, Gaggero A \& Diaz PV (1997) Respiratory syncytial virus infection in infants is associated with predominant Th-2-like response. American Journal of Respiratory and Critical Care Medicine 156, 190-195.

Ross DA \& Cutts FT (1997) Vindication of policy of vitamin A with measles vaccination. Lancet 350, 81-82.

Ruel MT, Rivera JA, Santizo MC, Lonnerdal B \& Brown KH (1997) Impact of zinc supplementation on morbidity from diarrhea and respiratory infections among Guatemalan children. Pediatrics 99, 808-813.

Ryan M, Gothefors L, Storsaeter J \& Mills KH (1997a) Bordetella pertussis-specific Th1/Th2 cells generated following respiratory infection or immunization with an acellular vaccine: comparison of the T cell cytokine profiles in infants and mice. Developments in Biological Standardization 89, 297-305.

Ryan M, Murphy G, Gothefors L, Nilsson L, Storsaeter J \& Mills KH (1997b) Bordetella pertussis respiratory infection in children is associated with preferential activation of type $1 \mathrm{~T}$ helper cells. Journal of Infectious Diseases 175, 1246-1250.

Schaumberg DA, O’Connor J \& Semba RD (1996) Risk factors for xerophthalmia in the Republic of Kiribati. European Journal of Clinical Nutrition 50, 761-764.

Semba RD (1997) Vitamin A supplementation. Lancet 350, 10311032.

Semba RD (1998) The role of vitamin A and related retinoids in immune function. Nutrition Reviews 56, S38-S48.

Semba RD, Akib A, Beeler J, Munasir Z, Permaesih D, Muherdiyantiningsih, Komala, Martuti S \& Muhilal (1997) Effect of vitamin A supplementation on measles vaccination in nine-month-old infants. Public Health 111, 245-247.

Semba RD, Lyles CM, Margolick JB, Caiaffa WT, Farzadegan H, Cohn S \& Vlahov D (1998) Vitamin A supplementation and human immunodeficiency virus load in injection drug users. Journal of Infectious Diseases 177, 611-616.

Semba RD, Miotti PG, Chiphangwi JD, Saah AJ, Canner JK, Dallabetta GA \& Hoover DR (1994) Maternal vitamin A deficiency and mother-to-child transmission of HIV-1. Lancet 343, 1593-1597.
Semba RD, Muhilal, Scott AL, Natadisastra G, Wirasasmita S, Mele L, Ridwan E, West KP Jr \& Sommer A (1992) Depressed immune response to tetanus in children with vitamin A deficiency. Journal of Nutrition 122, 101-107.

Semba RD, Muhilal, Ward BJ, Griffin DE, Scott AL, Natadisastra G, West KP Jr \& Sommer A (1993) Abnormal T-cell subset proportions in vitamin A-deficient children. Lancet 341, 5-8.

Semba RD, Munasir Z, Beeler J, Akib A, Muhilal, Audet S \& Sommer A (1995) Reduced seroconversion to measles in infants given vitamin A with measles vaccination. Lancet 345, 1330 1332.

Semba RD, Park S, Royal W \& Griffin DE (1996) Vitamin A deficiency and T-cell subpopulations in HIV-infected adults. Nutrition Research 16, 915-923.

Semba RD \& Tang AM (1999) Micronutrients and the pathogenesis of human immunodeficiency virus infection. British Journal of Nutrition 81, 181-189.

Shankar AH, Genton B, Semba RD, Tielsch J \& West KP Jr (1997) Vitamin A supplementation as a nutrient-based intervention to reduce malaria-related morbidity. In Abstracts of the XVIII International Vitamin A Consultative Group Meeting, Cairo, Egypt, p. 31. Washington, DC: The Human Nutrition Institute.

Sijtsma SR, Rombout JHWM, van der Zijpp AJ \& West CE (1990) Vitamin A deficiency impairs cytotoxic T lymphocyte activity in Newcastle disease virus-infected chickens. Veterinary Immunology and Immunopathology 26, 191-201.

Sklan D, Melamed D \& Friedman A (1994) The effect of varying levels of dietary vitamin A on immune response in the chick. Poultry Science 73, 843-847.

Solotorovsky M, Squibb RL, Wogan GN, Siegel H \& Gala R (1961) The effect of dietary fat and vitamin A on avian tuberculosis in chicks. American Review of Respiratory Diseases 84, 226-235.

Sommer A, Katz J \& Tarwotjo I (1984) Increased risk of respiratory disease and diarrhea in children with preexisting mild vitamin A deficiency. American Journal of Clinical Nutrition 40, 1090-1095.

Sommer A \& West KP Jr (1996) Vitamin A Deficiency: Health, Survival, and Vision. New York: Oxford University Press.

Sriramachari S \& Gopalan C (1958) Nutrition and tuberculosis: effect of some nutritional factors on resistance to tuberculosis. Indian Journal of Medical Research 46, 105-112.

Stabell Benn C, Aaby P, Balé C, Olsen J, Michaelsen KF, George E \& Whittle H (1997) Randomised trial of effect of vitamin A supplementation on antibody response to measles vaccine in Guinea-Bissau, west Africa. Lancet 350, 101-105.

Stephensen CB, Blount SR, Schoeb TR \& Park JY (1993) Vitamin A deficiency impairs some aspects of the host response to influenza A virus infection in BALB/c mice. Journal of Nutrition 123, 823-833.

Stephensen CB, Moldaveanu Z \& Gangopadhyay NN (1996) Vitamin A deficiency diminishes the salivary immunoglobulin A response and enhances the serum immunoglobulin $\mathrm{G}$ response to influenza A virus infection in BALB/c mice. Journal of Nutrition 126, 94-102.

Stoltzfus RJ, Jalal F, Harvey PWJ \& Nesheim MC (1989) Interactions between vitamin A deficiency and Plasmodium berghei infection in the rat. Journal of Nutrition 119, 2030-2037.

Stürchler D, Tanner M, Hanck A, Betschart B, Gautschi K, Weiss N, Burnier E, Del Giudice G \& Degrémont A (1987) A longitudinal study on relations of retinol with parasitic infections and the immune response in children of Kikwawila village, Tanzania. Acta Tropica 44, 213-227.

Sweet LK \& K'ang HJ (1935) Clinical and anatomic study of avitaminosis A among the Chinese. American Journal of Diseases of Childhood 50, 699-734. 
The Vitamin A and Pneumonia Working Group (1995) Potential interventions for the prevention of childhood pneumonia in developing countries: a meta-analysis of data from field trials to assess the impact of vitamin A supplementation on pneumonia morbidity and mortality. Bulletin of the World Health Organization 73, 609-619.

Tielsch JM, West KP, Katz J, Chirambo MC, Schwab L, Johnson GJ, Tizazu T, Swartwood J \& Sommer A (1986) Prevalence and severity of xerophthalmia in southern Malawi. American Journal of Epidemiology 124, 561-586.

Wagner G, Koram K, McGuinness D, Bennett S, Nkrumah F \& Riley E (1998) High incidence of asymptomatic malaria infections in a birth cohort of children less than one year of age in Ghana, detected by multicopy gene polymerase chain reaction. American Journal of Tropical Medicine and Hygiene 59, 115123.

Watson RR, Yahya MD, Darban HR \& Prabhala RH (1988) Enhanced survival by vitamin A supplementation during a retrovirus infection causing murine AIDS. Life Sciences 43, $13-18$.
West CE, Rombout JHWM, van der Zijpp AJ \& Sijtsma SR (1991) Vitamin A and immune function. Proceedings of the Nutrition Society 50, 251-262.

West KP Jr, Katz J, Shrestha SR, LeClerq SC, Khatry SK, Pradhan EK, Adhikari R, Wu LS, Pokhrel RP \& Sommer A (1995) Mortality of infants $<6$ mo of age supplemented with vitamin A: a randomized, double-masked trial in Nepal. American Journal of Clinical Nutrition 62, 143-148.

WHO/CHD Immunisation-Linked Vitamin A Supplementation Study Group (1998) Randomised trial to assess benefits and safety of vitamin A supplementation linked to immunisation in early infancy. Lancet 352, 1257-1263.

Yoneda T \& Ellner JJ (1998) CD4+ T cell and natural killer celldependent killing of Mycobacterium tuberculosis by human monocytes. American Journal of Respiratory and Critical Care Medicine 158, 395-403.

Zhao Z \& Ross AC (1995) Retinoic acid repletion restores the number of leukocytes and their subsets and stimulates natural cytotoxicity in vitamin A-deficient rats. Journal of Nutrition 125, 2064-2073. 
